\title{
ANALYSIS OF EXCHANGE RATE EFFECT ON TRADE BALANCE IN PAKISTAN
}

\begin{abstract}
Ali Nawaz*
Abstract

Exchange rate is becoming one of the major issues in trade balance of Pakistan. This study has studied the liaison between trade and exchange rate, income variables for 1990-2016. The Empirical investigation I applied Auto regression (AR) Model used in order to find the correlation between trade balance and other selected variables, this result suggests that trade is significantly positive related to rate of exchange, and inversely related to income during the selected sample period. The negative sign with income shows that the relationship between the determinants is negative or inversely related with Trade balance. On the other hand positive sign with exchange rate shows direct relationship with Trade balance.
\end{abstract}

Keywords: Trade Balance, Exchange rate, Income, Auto Regression Model

\section{Introduction}

Devaluation means correcting a trade deficit and balance of payments deficit. It increases the domestic price of imports and lowers the foreign export price. According to Bahmani and Alse (1995) study suggests against the system of devaluation. According to Hyder and Mehboob (2006), the government and policymakers are trying different currency rates in Pakistan. In the 1980s, real effective exchange rates (REER) increased mainly due to the US dollar's estimates of major currencies and higher domestic inflation. According to Zaiby (2009), Pakistan's imports are higher than the trade deficit. After 2006, the country is facing a constant depreciation in the rupee

\footnotetext{
* Department of Economics, Abdul Wali Khan University Mardan.
} 
against the dollar. Rashid and Asif (2010) examine the impact of devaluation on the trade balance in Pakistan. The study uses the Auto Regressive Distributed Lag Model (ARDL). The estimated period is from (1981-2008). The study results that devaluation improves the trade balance. It is recommended to increase the trade balance. The result also shows that the devaluation in trade and equilibrium is effective.

According to Halicioglu and Ferda (2008) finding the long term connection between effective real exchange rates and trade balance. According to Bicudo and Azu (2018) the effect of real bilateral exchange rate on China-Nigeria bilateral trade between countries and the volatility and third country bilateral exchange rate. The effects are determined on export and imports separately in short and long run. The Nigerian imports from china are negatively related to real bilateral exchange rate increase due to volatility and her exports to China are positively related in bilateral exchange rate mostly in short run. The Japan is integrated as third country in Nigerian market. The third country plays negative role in China-Nigeria trade.

In this study the problem is that Pakistani Economy has been facing the big problem of trade deficit since 1947. In Pakistan there is also political instability, corruption, money laundering which is the main problem of Pakistan due to which money is devalued after 1982 the country is undergoing a constant devaluation in the rupee contrary to dollar (Zaiby, 2009).

\section{Research Questions}

- What's the impact of real exchange rate on trade balance?

- Is there any positive or negative impact of income (GDP) on trade balance?

\section{Objectives of the Study}

Trade has big effect on a country's economy. The countries are developed as a result of better trade balance so data are collected from WDI in the order of analysis of the exchange rate effect on trade balance in Pakistan. Thus, this study aims to investigate for the impact of real exchange rate on trade balance in Pakistan. Most of the researchers and the economists have been working on exchange rate effect on trade but due to the differences time period and the different study area, the results are not the same. The present work is important because it studies the factors that are responsible in Pakistan for exchange rate effect on trade for the year 19902016. 
This study uses such pattern as follows. Section 1 discusses introduction of the study. Section 2 contains literature review. Data and Variables are discussed in section 3 tests of the data; results and conclusion are discussed in sections 4 , and 5 respectively.

\section{Literature Review}

\section{Literatures in General}

The study of Siddiqui and Akhtar (1999) examines the influence of changes in exchange rates on prices. This study uses the stationary cointegrating vector model for the estimated time period (1972-1998). The impact of changes in foreign and monetary terms. The study does not detect any momentous uni-directional or bi-directional causal liaison between changes in the rates of exchange and domestic prices. The researcher tries to find the money supply and level of activity that affect the domestic prices. This suggestion argues that the major determinants of domestic prices are not available. In order to accept or refute this argument, the researcher needs to disaggregate. Choudhri and Khan (2002) this study examines the Exchange rate and Consumer price in Pakistan. The study uses the simple Vector Auto-regression (VAR) for the estimated time period (1982-2001).

Shafiq and Razi (2012) examine the determinants of rate of exchange and its influence on Pakistan's economy. This study uses multiple regressions for the estimated time period (2001-2011). The study's results show that that the exchange rate and factor of economics of country have robust association. Khan and Ali (2016) found inverse coefficient of effective exchange rate suggest the absence of J-curve in case of Pakistan. Masih and Pervez (2018) examine the relationship between the exchange rate and trade balance in China. This study uses the J-curve and MarshallLerner condition. The full-sample data tests examine the TB and REER causal rapport but the TB and REER having no long run relationship. The time-varying rolling window methods to examine the dynamic fundamental relationship which show the REER have both negative and positive impact on trade. China has faced structural changes and economical transition in the exchange rate policy. Bicudo and Azu (2018) examine the special effects of bilateral real rate of exchange on Sino-Nigeria. This study uses ARDL model. This is conducted on the real bilateral exchange rate on ChinaNigeria bilateral trade, taking the volatility and third country bilateral exchange rate. The effects are determined on export and imports are 
separately in short and long run. The Nigerian imports from China are negatively related to real bilateral exchange rate increase due to volatility and her exports to China are positively in bilateral exchange rate mostly in short run. Japan is integrated as third country in Nigerian market. The third country plays negative role in China-Nigeria trade.

\section{Methodology}

The following chapter consists of empirical model and methodology, data and data source.

\section{Data Sources}

The data sources are time series data are used for time period of 1990 to 2016 to find the effect of rate of exchange on trade balance in Pakistan. All the variables data is collected from World Development Indicators (WDI) (2018).

\section{Variables of Study}

In this study the researcher uses three variables for finding the exchange rate effect on trade balance in Pakistan. In this study in hand, trade balance is used as the response variable, while the explanatory variables are exchange rate, income (GDP).

The constructive form of the model is as:

$$
\mathrm{Tb}=\mathrm{f}(\text { REER, GDP). }
$$

\section{Econometric Model}

In this study the researcher uses such model which is given below as

$y=\alpha+\beta x 1+\beta 2 x 2+\epsilon t \quad \ldots \ldots \ldots .$.

Where $\mathrm{y}=$ trade balance, $\quad \mathrm{X} 1=$ exchange rate, $\quad \mathrm{X} 2=$ gross domestic products,

$$
\alpha \beta=\text { parameters }, \quad \varepsilon t=\text { Error term }
$$




\section{Results and Discussion}

In this section the researcher includes Descriptive statistics, Tables and interpretation of the tables. In this section the researcher conducts the Augmented Dickey Fuller (ADF) test to find the stationary of the variables through unit root test. In most of time series data, the common assumption is stationary. In case of no stationary in the time series data, t-distribution results will not be valid. Therefore, to check whether the data has unit root or stationary the researcher uses ADF test for current study for the stationary of data. In this chapter the researcher also runs the model such Auto Regression and also interpretation of tables of the model.

Unit Root Test: A unit root test is defined as that if a time series variable is non-stationary then researcher possesses a unit root test. It is also called a unit root process or differences stationary process. If a time series has a unit root, it shows a systematic pattern that is unpredictable.

Testing for Stationary: In most of time series data, the common assumption is stationary. In case of no stationary in the time series data, tdistribution result will not be valid. Therefore, to check whether the data has unit root or stationary the researcher uses ADF test for current study for the stationary of data.

The table 4.1 represents the result of regression model used for analysis.

R-Squared: in the given table it can also be seen the value of R-squared which is (0.74) meaning that $74 \%$ are $\mathrm{X}$-variables have been explain during the study or estimated, the R-squared of the study is gone be greater than $60 \%$ meaning that it can be accepted the model because if the R-squared less than $60 \%$ than the model would have been rejected but in this case Rsquared is more than $60 \%$ which is a green signal.

P-value: The P-value is also less than $(0.05 \%)$ which is $(0.0000)$ meaning that the model cannot be rejected.

Durbin Watson Stat: The AR model table also shows that the Durbin Watson are more than (2) meaning that we accept the model because it is known that if the Durbin Watson value are close more than (2) the model be accepted rather less than (2) it would be rejected. 
The co-efficient value and T- value show the relationship between income and REER with Trade balance. According to results REER has positive impact on trade while the income impact is negative as show in the sign.

As Durbin Watson stat value is 0.71 which shows that there is no auto correlation problem. Overall significant of model can be tested by Tstatistics and its probability value.

Table 4.1: Result Auto Regression

\begin{tabular}{|l|c|c|c|c|}
\hline \multicolumn{1}{|c|}{ Variable } & Co-efficient & Std. Error & t-Statistic & Prob. \\
\hline C & $-2.13 \mathrm{E}+10$ & $9.26 \mathrm{E}+09$ & 2.296175 & 0.0307 \\
\hline REER & $1.60 \mathrm{E}+08$ & 88197315 & 1.813659 & 0.0823 \\
\hline INCOME & -1.236633 & 0.147168 & -8.402857 & 0.0000 \\
\hline Adj.R ${ }^{2}$ & 0.725191 & & & \\
\hline S.E. of regression & $4.08 \mathrm{E}+09$ & & & \\
\hline F-statistic & 35.30553 & & & \\
\hline Durbin-Watson stat & 0.716498 & \multicolumn{3}{|l|}{} \\
\hline
\end{tabular}

Table 4.2: Variables Test of Descriptive Statistics

\begin{tabular}{|l|c|c|c|}
\hline & Trade & Exchange rate & Income \\
\hline Mean & $-9.28 \mathrm{E}+09$ & 105.9502 & $4.01 \mathrm{E}+09$ \\
\hline Median & $-5.10 \mathrm{E}+09$ & 104.4697 & $2.16 \mathrm{E}+09$ \\
\hline Maximum & $-4.08 \mathrm{E}+08$ & 122.8127 & $1.71 \mathrm{E}+10$ \\
\hline Minimum & $-2.48 \mathrm{E}+10$ & 93.48988 & $-9.36 \mathrm{E}+08$ \\
\hline Std. Dev. & $7.77 \mathrm{E}+09$ & 9.295286 & $5.57 \mathrm{E}+09$ \\
\hline Skewness & -0.55247 & 0.21369 & 1.223493 \\
\hline Kutosis & 1.820391 & 1.739528 & 3.128842 \\
\hline Jarque-Bera & 2.938937 & 1.992875 & 6.75488 \\
\hline Probability & 0.230048 & 0.369192 & 0.034135 \\
\hline Sum & $-2.51 \mathrm{E}+11$ & 2860.656 & $1.08 \mathrm{E}+11$ \\
\hline Sum Sq. Dev. & $1.57 \mathrm{E}+21$ & 2246.461 & $8.07 \mathrm{E}+20$ \\
\hline Observations & 27 & 27 & 27 \\
\hline
\end{tabular}

In the Table 4.1 where the value of $\mathrm{R}$-squared is $74 \%$ which means the $\mathrm{X}$ variable are explained in this study which is value greater than $60 \%$ due to which the researcher accepts the model. The P-value if this is $(0.05 \%)$ or greater than it the researcher will reject the model but this is 0.0000 here in 
such case the researcher accepts the model. The Durbin Watson value "2" or more than it the researcher will reject the model but here in the table our result value is 0.71 . According to the result the negative sign with income shows the relationship between the determinants that is negative or inverse with Trade balance. Which mean there is negative relation between Trade balance and income (GDP). There is negative impact of Trade on GDP of the country in case of Pakistan. The positive sign with real effective exchange rate which shows the green signal for us which means there is positive relation between rate of exchange and balance of trade of the country. The rate of exchange and balance of trade have direct relation with each other. Results of the present study are in line with the results of Siddiqui and Akhtar (1999), Rashid and Asif (2010), Haseeb et al (2014), Prabhakar et al. (2015), Irwan et al. (2015), Sani et al. (2016), Khan et al. (2016), Khan and Ali (2016), Yien et al. (2017), Shah et al. (2016), Muhammad \& Khan (2017), Masih and Pervez (2018) and Bicudo and Azu (2018).

\section{Conclusion and Recommendation}

The purpose of the present study is to know about the impact of rate of exchange on balance of for Pakistan during1990 to 2016, and data are collected from different sources including WDI. Additionally, the test of stationarity of variables is conducted and performed as unit root test. The trade balance, exchange rate is stationary on $1^{\text {st }}$ difference and income is stationary on $2^{\text {nd }}$ difference. The Trade Balance is taking as dependent variable and independent are Exchange rate, income (GDP). According to the result the negative sign with income shows the relationship between the determinants is negative or inverse with Trade balance. On the other hand positive sign with exchange rate showing direct relationship with Trade balance. Pakistan growth rate is not satisfactory due to factors like political instability, terrorism, energy crisis, security situation and unsuitable policies. Our imports are mostly machinery, medicines, petrol and exports are agriculture product due to balance of payments miss unfavorable.

\section{Policy of Recommendation}

On the basis of above findings, it is recommended by the researcher that in order to control the trade balance and exchange rate of Pakistan we need to improve economic growth of the country, support the private sector and remove instability from country. 
It is recommended for the people who are making policies for the country to keep in mind that inter relationship of all these variables, as they can bring trade balance in Pakistan. On the basis of result of the study, it is recommended to have a combination of fiscal and monetary policy that will bring improvement in the trade as well.

\section{References}

Bahmani-Oskooee, M., \& Alse, J. (1995). Is there any long-run relation between the terms of trade and trade balance? Journal of Policy Modeling, 17(2), 199-205.

Bicudo, J.F., \& Azu, N.P. (2018). Effects of Bilateral Real Exchange Rate on Sino-Nigeria Trade: An ARDL Cointegration Approach. International Journal of Economics and Finance, 10(7), 125.

Choudhri, E.U., \& Khan, M.S. (2002). The exchange rate and consumer prices in Pakistan: is rupee devaluation inflationary? The Pakistan Development Review, 107-120.

Halicioglu, and Ferda. (2008). The bilateral J-curve: Turkey versus her 13 trading partners. Journal of Asian Economics, 19(3), 236-243.

Haseeb, M., N.H. Hartani, N.A.A. Bakar, Azam M. \& Hassan, S., (2014). Exports, foreign direct investment and economic growth: Empirical evidence from Malaysia (1971-2013). American Journal of Applied Sciences, 11: 1010-1015.

Hyder, Z., \& Mahboob, A. (2006). Equilibrium real effective exchange rate and exchange rate misalignment in Pakistan. SBP Research Bulletin, 2(1), 6-27

Irwan S., Haseeb, M., Azam M. \& Islam, R., (2015). Foreign direct investment, financial development, international trade and energy consumption: Panel data evidence from selected ASEAN countries. International Journal of Energy Economics and Policy 5(3), 841-850.

Khan, S., Azam, M., \& Chandra, E., (2016). Import demand, income elasticity and growth rate in Pakistan: the impact of trade liberalization. Foreign Trade Review, 51(3), 1-12

Muhammad, A., \& Khan A.Q., (2017). Growth-Corruption-Health Triaca and environmental degradation: Empirical evidence from Indonesia, Malaysia and Thailand. Environmental Science and Pollution Research, 24: $16407-16417$

Prabhakar, A., C., Azam, M., Bakhtyar, B., \& Ibrahim, Y., (2015). Foreign direct investment, trade and economic growth: a new paradigm of the BRICS. Modern Applied Science, 9(12): 32-42 
Rahid, M. A. K. (2010). Time series analysis of real effective exchange rates on trade balance in Pakistan. Journal of Yaşar University, 5(18), 30383044.

Razi, A., Shafiq, A., Ali, S.A., \& Khan, H. (2012). Determinants of exchange rate and its impact on Pakistani economy. Global Journal of Management and Business Research, 12(16), 43-56

Sani, IA., Hassan, S., \& Azam, M., (2016). Effects of exchange rate volatility on outputs in some selected West Africa countries. International Journal of Development and Economic Sustainability, 4(1), 1-10

Siddiqui, R., \& Akhtar, N. (1999). The impact of changes in exchange rate on prices: a case study of Pakistan. The Pakistan Development Review, 1059-1066.

Shah, S.W. A., Bakar, N.A., \& Azam, M., (2016). Foreign direct investment, economic growth and terrorism events in Pakistan: a co-integration analysis. International Journal of Academic Research in Economics and Management Sciences, 5(4), 155-167

Thanh, N.N., \& Kalirajan, K. (2006). Can devaluation be effective in improving the balance of payments in Vietnam? Journal of Policy Modeling, 28(4), 467-476.

Yien, L, Hussin, A, \& Azam, M., (2017). Granger causality analysis between inflation, debt and exchange rate: evidence from Malaysia. International Journal of Academic Research in Accounting, Finance and Management Sciences, 7(1), 189-196

Zaiby, P. (2009). Currency Devaluation and its Impact on the Economy, Accessed on Dec 9, 2009. 